\title{
MATHEMATIKA
}

A JOURNAL OF PURE AND APPLIED MATHEMATICS

Edited by

H. DAVENPORT, W. R. DEAN,

J. G. SEMPLE

VOLUME 4

1957

Published by

THE DEPARTMENT OF MATHEMATICS

UNIVERSITY COLLEGE

LONDON 
Printed by

C. F. HODGSON \& SON, LTD.

23 PAKENHAM STREET

LONDON, W.C.1 


\section{INDEX TO VOLUME 4}

ARMITAGE, J. V. The product of $n$ linear forms in a field of series . . . $\quad \ldots \quad 132$

BIRCH, B. J. Homogeneous forms of odd degree in a large number of variables $\quad \ldots \quad 102$

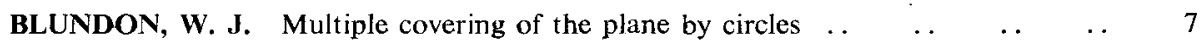

BOSANQUET, L. S. and TATCHELL, J. B. A note on summability factors $\quad$. 25

BURGESS, D. A. The distribution of quadratic residues and non-residues $\ldots$. $\quad 106$

CHANDRASEKHAR, S. On the expansion of functions satisfying four boundary $\begin{array}{lllllllllllll}\text { conditions } & \ldots & \ldots & \ldots & \ldots & \ldots & \ldots & \ldots & \ldots & \ldots & \ldots & 140\end{array}$

COHN, P. M. Groups of order automorphisms of ordered sets $\quad \ldots \quad \ldots \quad$. $\quad 41$

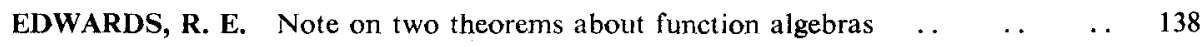

FRÖHLICH, A. On a method for the determination of class number factors in

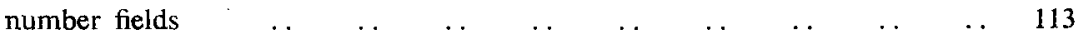

GLADWELL, G. M. L. Uniqueness theorems for thin clamped anisotropic plates 70

$\begin{array}{llllllll} & \text { On the solution of problems of dynamic plane elasticity } & \ldots & \ldots & \ldots & 166\end{array}$

LEWIS, D. J. Cubic forms over algebraic number fields $\quad \ldots \quad \ldots \quad \ldots \quad$. $\quad \ldots \quad \ldots \quad 97$

MAHLER, K. On the fractional parts of the powers of a rational number (II) $\quad \ldots \quad 122$

MAULDON, J. G. An inversion formula for a generalized transform $\quad \ldots \quad \ldots \quad 146$

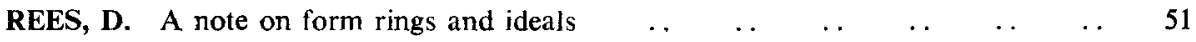

RIDOUT, D. Rational approximations to algebraic numbers.. $\quad \ldots \quad \ldots \quad \ldots \quad \ldots \quad 125$

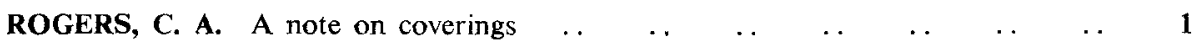

SEGEDIN, C. M. The relation between load and penetration for a spherical punch 156

SINGH, R. K. P. The Green's function of an elliptic plate $\quad \ldots \quad \ldots \quad \ldots \quad \ldots \quad \ldots \quad 61$

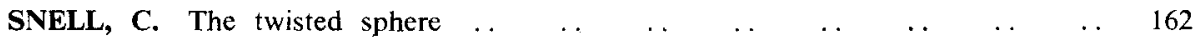

TATCHELL, J. B. See Bosanquet, L. S.

WATSON, G. L. Bounded representations of integers by quadratic forms $\quad \ldots \quad \ldots \quad 17$

WIGGLESWORTH, L. A. Stress distribution in a notched plate $\quad \ldots \quad \ldots \quad$. $\quad 76$ 